\title{
Evaluation of economic security in the Ural region in the context of development of small and medium-sized enterprises
}

\author{
Natalya Yu. Vlasova $\bowtie$, Olesya O. Kalganova \\ Ural State Economic University, Ekaterunburg, Russia; email: nat-vlasova@yandex.ru
}

\section{ABSTRACT}

Enhancing economic security of regions is crucial for the development of the whole country, which is what makes research in this sphere particularly important. This study aims to analyze and compare the economic security data on the regions constituting the Ural Federal District (Russia). In contrast with current studies in the field, we are conducting detailed analysis of the factors that affect the development of small and medium-sized enterprises (SMEs) and business climate in the regions. The conceptual framework of this research relies on entrepreneurship theories and theoretical approaches to analysis and evaluation of regional economic security. We develop methodology based on sets of quantitative and qualitative indicators and apply analytical, comparative and statistical methods as well as the method of expert evaluation. The data are provided by the regional statistic services and business support foundations. We also analyze regional support programs for small and medium-sized businesses. We found that all regions of the Ural Federal District are characterized by the medium (acceptable) level of economic security and moderate risk. In the economic security ranking, Tyumen region is at the top while the second place is occupied by Sverdlovsk region; Chelyabinsk and Kurgan regions are at the bottom.
\end{abstract}

\author{
KEYWORDS \\ region, regional economic \\ security, small and middle-sized \\ enterprises, entrepreneurship, \\ business support programs, Ural \\ Federal District
}

\section{FOR CITATION}

Vlasova, N. Yu., Kalganova, O. O. (2018) Evaluation of economic security in the Ural region in the context of development of small and medium-sized enterprises. R-economy, 4(3), 121-129. doi: 10.15826/recon.2018.4.3.017

\section{Оценка экономической безопасности в уральском регионе в контексте развития малых и средних предприятий}

\author{
Н. Ю. Власова $\bowtie$, О. О. Калганова \\ Уральский государственный экономический университет, Екатеринбург, Россия; \\ email:nat-vlasova@yandex.ru
}

\section{PEЗЮME}

Укрепление экономической безопасности регионов имеет важное значение для развития всей страны, что делает исследования в этой сфере крайне важными. Данное исследование направлено на анализ и сравнение данных экономической безопасности в регионах, входящих в Уральский федеральный округ (Россия). В отличие от текущих исследований в данной области, мы провели детальный анализ факторов, влияющих на развитие малых и средних предприятий (МСП) и делового климата в регионах. Концептуальные рамки этого исследования основаны на теориях предпринимательства и теоретических подходах к анализу и оценке региональной экономической безопасности. Мы разработали методологию на основе наборов количественных и качественных показателей и применили аналитические, сравнительные и статистические методы, а также метод экспертной оценки. Данные предоставлены региональными службами статистики и поддержки бизнеса. Мы также анализируем региональные программы поддержки малого и среднего бизнеса. Мы обнаружили, что все регионы Уральского федерального округа характеризуются средним (приемлемым) уровнем экономической безопасности и умеренным риском. В рейтинге экономической безопасности Тюменская область находится на вершине, а второе место занимает Свердловская область; Челябинская и Курганская области находятся внизу.

\section{КЛЮЧЕВЫЕ СЛОВА}

регион, региональная экономическая безопасность, малые и средние предприятия, предпринимательство, программы поддержки бизнеса, Уральский федеральный округ

\section{ДЛЯ ЦИТИРОВАНИЯ}

Vlasova, N. Yu., Kalganova, O. O. (2018) Evaluation of economic security in the Ural region in the context of development of small and medium-sized enterprises. R-economy, 4(3), 121-129. doi: 10.15826/recon.2018.4.3.017 


\section{Introduction}

Global economic instability has made the question of regional economic security crucial for the prosperity of countries. In its turn, economic security of regions depends on multiple factors and conditions, which include the quality of the human capital, the general level of economic development and associated processes, the quality of the infrastructure, the availability and diversity of resources, political stability and so on. The region's attractiveness for investment and the level of entrepreneurial activity are also important factors for its economic security.

The vast majority of studies confirm that small and medium-sized businesses (SMEs) are among the key drivers of economic growth. There is also evidence that not only does SME development positively affect the general economic performance of the region, but also has a significant social impact, which is crucial for regional and local economy. SMEs contribute to the development of entrepreneurship and improve business climate, moreover, they help the government tackle the problem of welfare mentality by encouraging people to look after themselves. Small and medium-sized businesses are essential for innovation-driven sectors of economy as it is primarily in such enterprises that new products and technologies are created and tested. Therefore, the development of SMEs and self-employment is an important factor that determines the region's economic security. There is, however, a lack of adequate methodology to evaluate the impact of SME development on the level of economic security and our study is going to address this issue.

\section{Theoretical framework}

This research is based on two groups of theoretical approaches. The first group comprises theories on economic security in regions. These theories mostly focus on threshold values of various economic and social indicators that are crucial for stable regional development. The second group includes theories of entrepreneurship, especially the ones that deal with small- and medium-sized businesses.

There is a vast body of research literature discussing the problems of economic security in regions. A thorough retrospective analysis of these problems was conducted by the Ural research school [1]. In general terms, economic security on the regional level is seen as "a complex of con- ditions and factors that characterize the current state of regional economy, its stability and progressive growth as well the degree of its independence in the processes of integration with federal economy" [1, p. 29].

The following methods are applied in Russian studies to evaluate the level of economic security:

a) monitoring of the key macroeconomic indicators, especially when their values approach the threshold values [2];

b) expert evaluation and ranking of regions according to the level of security threat [3];

c) evaluation of the consequences of security threats by measuring the damage [1].

Mingaleva and Gershanok show the connection between the region's stability, its competitiveness and the level of economic security [4]. In some studies, economic security of small-sized businesses is seen as an important factor and as a criterion for evaluating economic security of the region and the whole country $[5 ; 6]$.

Undoubtedly, the more active local business life is, the stronger is the positive effect that SMEs have on regional economy [7]. Therefore, we should have a good understanding of the factors and conditions that influence the entrepreneurial climate in the region, for example, by analysing policies aimed at supporting entrepreneurship and evaluating their efficiency [8-12]. Some studies focus on specific forms of such support that target small businesses. For instance, Korchagina analyzes the state policy of stimulating the development of clusters of small and medium-sized enterprises [13]. Other studies question the long-term efficiency of such policies and emphasize the fact that the quality of human capital, population mobility and density are much more important $[14 ; 15]$.

A big group of studies analyze SME support programs in transitive economies [16-18].

\section{Data and Methodology}

Our methodology for economic security evaluation relies primarily on the indicators of SME development.

The methodology comprises both quantitative and qualitative parameters. For the former we used the official statistical data while the latter require additional research and expert evaluations.

Economic security implies stability that ensures sustainable growth of the region's economy, which means that, in order to evaluate its current state, we should be focusing on the ongoing trends and patterns of regional development. 
We estimate the parameters by applying a tenpoint scale with the higher values corresponding to better performance: if the current values are lower than the target value, the region scores 0 . If the current values are closer to the average value, the region scores 5 . If the current values meet the target values, then the region scores 10 .

The indicators used to evaluate regional security with the focus on SME development are shown in Table 1.

Indicators of regional economic security (with the focus on SME development)

\begin{tabular}{|c|c|}
\hline Quantitative indicators & Qualitative indicators \\
\hline $\begin{array}{l}\text { The number of SMEs } \\
\text { The number of employees } \\
\text { in SMEs } \\
\text { The share of SME turnover } \\
\text { in the GRP } \\
\text { The amount of taxes paid by } \\
\text { SMEs to the budget } \\
\text { Funds for SME support } \\
\text { from the federal and region- } \\
\text { al budgets } \\
\text { The number of financial } \\
\text { support recipients } \\
\text { The number of non-finan- } \\
\text { cial support recipients } \\
\text { The number of jobs created } \\
\text { by support recipients } \\
\text { Capital investment }\end{array}$ & $\begin{array}{l}\text { The quality of SME support } \\
\text { infrastructure } \\
\text { Efficiency of SME support } \\
\text { programs } \\
\text { Red tape (registration and } \\
\text { re-registration procedures } \\
\text { for businesses) } \\
\text { The level of entrepreneurial } \\
\text { activity } \\
\text { Attitude of local inhabitants } \\
\text { towards entrepreneurship } \\
\text { Access to information about } \\
\text { the market, its potential } \\
\text { and resources, production } \\
\text { facilities and equipment } \\
\text { Opportunities for further } \\
\text { development of SMEs }\end{array}$ \\
\hline
\end{tabular}

Let us now consider these indicators and their impact on regional economic security in more detail.

1. Quantitative indicators (better performing regions score 10; if no significant changes are registered, 5; and if the trend is negative, 0 ):

a) the number of SMEs, that is, the number of legal entities operating in the region as of the end of the financial year. The growth in the number of SMEs signifies that the region's economic security is improving as enterprises are participating in social and economic development of the region by contributing to its stability and prosperity;

b) the number of employees in SMEs. The rising number of employees working for small, medium-sized and micro-enterprises has a positive impact on economic security as it means more jobs. SMEs perform a vital social function as they reduce the level of unemployment and relieve social anxiety;

c) the share of people employed by SMEs. In the way similar to the previous indicator, its growth is beneficial for regional economic security. We apply the following formula to calculate it:

$$
\begin{aligned}
& \begin{array}{l}
\text { The share } \\
\text { of people } \\
\text { employed } \\
\text { by SMEs }
\end{array}=\frac{\begin{array}{c}
\text { The number } \\
\text { of SME employees }
\end{array}}{\text { The Workforce }} 100 \% . \\
& \text { Number in the Region }
\end{aligned}
$$

d) the turnover of SMEs. An increase in the turnover of SMEs shows that the needs of the regional population for products and services are fully (or to the fullest extent possible) satisfied and that the contribution of SMEs to the GRP is increasing;

e) the share of SME turnover in the GRP. An increase in the share of SME turnover indicates an increase in the GRP per capita. According to some experts, in order to make businesses and the region competitive and to achieve the necessary level of economic security, the share of SME turnover must be $60 \%$. We apply the following formula to calculate it:

$$
\begin{gathered}
\text { The share of } S M E \\
\text { turnover in the GRP }
\end{gathered}=\frac{\text { SME turnover }}{G R P} 100 \% \text {. }
$$

f) the total amount of tax paid by SMEs. An increase in the total amount of taxes paid by SMEs also reflects improved economic security in the region;

g) funds spent on SME support from the federal and regional budgets. A decrease in the amount of funds spent on SME support is detrimental to SME development as some of the businesses would then find themselves struggling to survive;

h) the number of recipients of financial support, which include both non-repayable subsidies and grants) and repayable assistance (guarantees, microloans, subsidized loans). An increase in this indicator should enhance entrepreneurial activity (the number of SMEs, the number of employees in SMEs, SME turnover, and so on);

i) the number of recipients of non-financial support, which includes consulting, training, and so on. This kind of support helps entrepreneurs deal with the lack of the relevant skills and knowledge. A competent entrepreneur is crucial for the success of his or her business and for ensuring economic security of the region;

k) the number of jobs created by support recipients. An increase in the number of jobs shows the efficiency of support programs, which in the long run affects the region's economic performance and economic security;

1) capital investment. A business can grow if it receives enough investment, which allows it to 
modernize its equipment and production facilities and launch new product lines. Through capital investment SMEs enhance the quality of their production and services, which positively affects the consumer demand.

2. Qualitative indicators: if the value of an indicator is high, the region scores 10; if low (unsatisfactory), 0 :

a) The region's SME support infrastructure is evaluated by looking at the number of business support organizations. Development and improvement of the SME support infrastructure shows the level of regional economic security;

b) Efficiency of SME support programs is evaluated by comparing indicator values with the total amount of spending on SME support in the region (state programs realized on different levels). To analyze the region's performance in this indicator we need the data provided by the program implementation reports. If $80-100 \%$ of the program's objectives and targets are met, then the region scores 10; if $50-79 \%, 5$; and if less than $50 \%, 0$.

c) Red tape and administrative barriers. Complexity of the procedure of registration or re-registration can prove to be a serious impediment to the development of SMEs discouraging people from starting up a new business. The more complex these procedures are, the harder it is to start a business, which causes a decline in the number of SME turnover in the GRP and is detrimental for economic security and vice versa, the simpler the procedure is, the higher the region scores in this indicator;

d) the level of entrepreneurial activity. The growing number of people willing to start their own business means that more new companies will be created in the region and that their contributions to the region's economic security will be more substantial;

e) social attitudes towards entrepreneurship. If local inhabitants demonstrate a positive attitude towards private business, it is beneficial for the socio-economic and political situation in the region.

f) Access to information about the market and its resources, the available production facilities and equipment is vital for the success of a business. If entrepreneurs are well-informed about the available resources, they have more opportunities to contribute to economic development and economic security of the region.

g) opportunities for SME development. This indicator corresponds to the region's attractiveness for investment and the overall level of economic activity.

Thus, our methodology comprises eighteen indicators: 11 quantitative and 7 qualitative. In each indicator, the region can score from 0 to 10 . The maximum total score is 180 ; the minimum, 0 . Ranking scores:

a) the score of 121-180 corresponds to $A$ ranking or a high level of economic security. The main indicators of SME development show positive dynamics; there is a growth in the number of local businesses. The contribution of SMEs to the GRP is increasing as new jobs are created and businesses pay more taxes to the budget. The region is in a riskfree zone.

b) the score of $61-120$ corresponds to $B$ ranking, which is a medium (acceptable) level of economic security. The main indicators of SME development remain stable and may show insignificant (positive or negative) changes. SMEs are enjoying sustainable growth; the state support is efficient although not to the fullest extent. The region is thus in the zone of acceptable risk, which should be monitored in case the situation deteriorates.

c) the score of 0-60 corresponds to $C$ ranking, which is a low (disastrous) level of economic security. The main indicators of SME development show negative dynamics: enterprises shut down, their turnover falls and so is the number of their employees. The production of SMEs is no longer in demand. The SME sector is in recession and support measures are ineffective. The region is subject to severe risk, which requires the authorities to take urgent measures to lower the risk level.

\section{Results}

Let us now look at the level of economic security in Sverdlovsk region in 2016 by focusing on SME development indicators. The scores for each indicator are shown in Table 2.

The exponential growth in the turnover of SMEs in 2016 in comparison with 2015 was determined by the actual turnover growth but also by the changes in the criteria of classifying businesses according to their size and annual revenues (see the Decree of the Government of the Russian Federation No 702 of 13.07. 2015).

The workforce number in Sverdlovsk region in 2015 was 2,293.1 thousand people and in 2016, $2,230.1$ thousand. Thus, by applying formula (1), we have calculated that the share of people employed in SMEs in the region was $18.8 \%$ in 2015 and $19.6 \%$ in 2016 of the total workforce. 
Table 2

Quantitative indicators of economic security in Sverdlovsk region

\begin{tabular}{|l|r|r|r|r|}
\hline \multicolumn{1}{|c|}{ Indicator } & \multicolumn{1}{c|}{$\mathbf{2 0 1 5}$} & \multicolumn{1}{c|}{$\mathbf{2 0 1 6}$} & Absolute change & \multicolumn{1}{l|}{ Score } \\
\hline Number of SMEs & 8,589 & 4,601 & $-3,988$ & 0 \\
\hline Number of employees in SMEs (ths people) & 233.01 & 134.26 & -98.75 & 0 \\
\hline Share of employees in SMEs (\%) & 10.16 & 6.02 & -4.14 & 5 \\
\hline Turnover of SMEs (bln rbs) & 546.55 & 530.32 & -16.23 & 5 \\
\hline Share of SME turnover in the GRP (\%) & 29.98 & 26.81 & -3.14 & 5 \\
\hline Total amount of tax paid by SMEs, ths rbs & $23,952,263$ & $26,536,719$ & $+2,584,456$ & 10 \\
\hline $\begin{array}{l}\text { Funds spent on SME support (from federal and regional } \\
\text { budgets) (mln rbs) }\end{array}$ & 815.3 & 640.7 & -174.6 & 0 \\
\hline Number of financial support recipients & 744 & 922 & +178 & 10 \\
\hline Number of non-financial support recipients & 10,352 & 8,665 & $-1,687$ & 0 \\
\hline Number of jobs created by support recipients & 2,532 & 2,438 & -94 & 5 \\
\hline Capital investment (mln rbs) & $9,335.5$ & $7,172.4$ & $-2,163.1$ & 0 \\
\hline Total score & & & & 40 \\
\hline
\end{tabular}

Source: Based on the data of Sverdlovsk Regional Business Support Foundation. Retrieved from https://sofp.ru/

The GRP in Sverdlovsk region in 2015 was $1,822.8$ billion roubles and in $2016,1,978.1$ billion. By applying formula (1), we can calculate that the SME turnover accounted for $60.2 \%$ in 2015 and $73.4 \%$ in 2016 . For a region to be competitive, this value should exceed $60 \%$.

The state SME support program is a part of the subprogram Impetus for Business of the state program Enhancement of Sverdlovsk Region's Attractiveness for Investment Until 2024 approved by the decree No 1002-ПП of 17.11.2014 of the Government of Sverdlovsk Region. Federal spending cuts caused cuts in financial support for SME development.

Sverdlovsk region enjoys a well-developed multi-level infrastructure for SME support. The core of this infrastructure is Sverdlovsk Regional Foundation for Business Support, created in 2002. Therefore, the region scores high in this indicator -10 .

The efficiency of SME support programs in Ekaterinburg was $87 \%$, which means that the region is quite successful in this indicator and scores 10.

Analytical centre Expert-Ural has studied the current state and problems of SME development in Sverdlovsk region and found that only $11.8 \%$ of entrepreneurs surveyed complained about regulatory and administrative barriers, in particular the complicated procedure of registration and re-registration. Since the registration procedure is neither simple nor fast, in this indicator the region scored only 5 .

As for the level of entrepreneurial activity, the introduction of a tax holiday in the region has proven to be efficient (see the law On Setting Tax Rates and the Introduction of Simplified Tax Compliance Procedures for Specific Categories of Tax Payers in Sverdlovsk Region). Not only did this measure stimulate entrepreneurial activity but it also led to the creation of new jobs, according to the data provided by the press service of the region's legislative assembly.

Recent studies have shown that the popularity of entrepreneurship has been increasing among local inhabitants. Potential businessmen are able to receive timely and quality access to information about the SME support system in the region. There is also a complex of measures being realized to stimulate youth entrepreneurship, for example, career guidance services and entrepreneurial training.

As for the access to information about the market, its resources, production facilities and equipment, it does not seem to be a serious problem for regional entrepreneurs. According to the study of Expert-Ural, the majority of business managers $(58.3 \%)$ are well informed about the market resources. The information is provided through on-line sources, governmental agencies and municipal services.

The key factors contributing to the development of SMEs in Sverdlovsk region are the internal market, large enterprises, and comparatively high purchasing power. In Expert $R A$ ranking, Sverdlovsk region has been classified as having a high investment potential combined with the moderate level of risk. Entrepreneurs themselves evaluate the economic situation in their target markets until 2020 the following way: $48.6 \%$, as 
quite favourable; $36.3 \%$, as favourable (the data of Expert-Ural). Thus, in this indicator the region scores 10.

The total region score, both in qualitative and quantitative indicators, is 100 . In 2016, Sverdlovsk region ranked in the category $B$, that is, the medium (acceptable) level of economic security. The values of the main SME-related indicators remained virtually unchanged, that is, the negative/ positive changes were insignificant. Even though the support programs are not fully effective, they manage to provide stable SME development and the region is in the zone of acceptable risk. Even with an insignificant improvement in the SME-related indicator values the region is likely to go up in the ranking by reaching $A$ category or a high level of economic security.

Table 3 shows qualitative indicators used for evaluation of economic security in Sverdlovsk, Chelyabinsk, Kurgan and Tyumen regions.

The Strategy of Socio-Economic Development of the Ural Federal District Until 2020 considers SMEs as one of the key instruments for using human, innovation and investment potential to raise the living standards and ensure sustainable development of this area.

Table 4 shows quantitative indicators of economic security in Chelyabinsk, Kurgan and Tyumen regions. We analyzed the official statistical data for the federal and regional levels and implementation reports for state SME support programs. According to Rosstat's data on the workforce in Chelyabinsk region, in 2015 there were $1,856.9$ thousand people and in $2016,1,850.2$ thousand. In Kurgan region, in 2015, 424.6 thousand and in 2016, 411 thousand. In Tyumen region, in 2015, 1,934.1 thousand people and in
2016, 1,956.6. By applying formula (1), we can calculate the share of employees in regional SMEs from the total number of workforce.

According to Rosstat's data, in 2015, the GRP in Chelyabinsk region was $1,209.2$ billion roubles; in 2016, 1,260.7 billion. In Kurgan region, the GRP in 2015 was 179.4 billion roubles and in 2016, 193.9 billion. In Tyumen region, in 2015, the GRP was 5,851.6 billion roubles and in 2016, 5,922.1 billion. By applying formula (2), we can calculate the share of the SME turnover in the GRP of these regions.

Since 2009, a SME support foundation has been operating in Chelyabinsk region. The SME support infrastructure in this region also includes the Regional Integrated Centre; the state-funded Innovation Business Incubator of Chelyabinsk Region, the Foundation for Industrial Development of Chelyabinsk Region, and the Engineering Centre of Chelyabinsk Region. In 2017, an organization called Business Territory was created that united all the existing SME support structures. Thus, we can conclude that Chelyabinsk region has a well-developed SME support infrastructure and it scores 10 in this indicator.

Kurgan region has a guarantee fund and a microfinance fund as well as organizations for non-financial support of SMEs - four business incubators, a techno-park, Kurgan Regional Export Support Centre, Centre for Youth Innovation, Centre for Cluster Development of Kurgan Region, and municipal business consulting centres. Therefore, Kurgan region also scores 10 in this indicator.

Tyumen region has the following SME infrastructure support organizations: foundation Investment Agency of Tyumen Region; a microfinance fund; a guarantee fund; Centre for Entre-

Table 3

Qualitative indicators of economic security in Ural regions in 2016

\begin{tabular}{|c|c|c|c|c|}
\hline \multirow[t]{2}{*}{ Indicator } & \multicolumn{4}{|c|}{ Score } \\
\hline & $\begin{array}{c}\text { Sverdlovsk } \\
\text { region }\end{array}$ & $\begin{array}{c}\text { Chelyabinsk } \\
\text { region }\end{array}$ & $\begin{array}{c}\text { Kurgan } \\
\text { region }\end{array}$ & $\begin{array}{c}\text { Tyumen } \\
\text { region }\end{array}$ \\
\hline SME support infrastructure & 10 & 10 & 10 & 10 \\
\hline Efficiency of SME support programs & 10 & 10 & 5 & 10 \\
\hline Red tape (registration and re-registration of businesses) & 5 & 5 & 5 & 10 \\
\hline Level of entrepreneurial activity & 10 & 5 & 5 & 10 \\
\hline Social attitudes towards entrepreneurship in the region & 10 & 5 & 5 & 5 \\
\hline $\begin{array}{l}\text { Accessibility of information about the market, its potential and resources } \\
\text { for development; about the available production facilities and equipment }\end{array}$ & 5 & 5 & 5 & 5 \\
\hline Potential for further SME development & 10 & 10 & 10 & 5 \\
\hline Total score & 60 & 50 & 45 & 55 \\
\hline
\end{tabular}

Note: Based on expert evaluations. 
preneurship Support; Centre for Coordination of Export-Oriented SME Support; state-funded Regional Business Incubator, which has offices in Tyumen, Tobolsk and Ishim; techno-park Western Siberian Innovation Centre of Oil and Gas. Thus, Tyumen region also scores 10 .

Our calculations have shown that in 2016, the efficiency of the subprogram SME Support and Development in Chelyabinsk Region in 2016-2019, which is a part of the larger state program Economic Development and Innovative Economy of Chelyabinsk Region in 2016-2019, was 84\% (0.844).
As for the implementation of the SME support model, Tyumen region is the top perfromed by reaching the level of $98 \%$.

According to the SME organization Opora Russia, in Chelyabinsk region starting a new business is difficult rather than easy while the situation in Tyumen region is the opposite: it is easy rather than difficult. Both Tyumen and Chelybinsk regions have created favourable conditions for business development, which means that they both score 10 in this indicator. As for Kurgan region, it scores lower in all the rankings.

Quantitative indicators of economic security in Chelyabinsk, Kurgan, and Tyumen regions

\begin{tabular}{|c|c|c|c|c|c|c|c|c|c|c|c|c|}
\hline \multirow[t]{2}{*}{ Indicator } & \multicolumn{4}{|c|}{ Chelyabinsk region } & \multicolumn{4}{|c|}{ Kurgan region } & \multicolumn{4}{|c|}{ Tyumen region } \\
\hline & 2015 & 2016 & \begin{tabular}{|l|}
$\begin{array}{c}\text { Absolute } \\
\text { change }\end{array}$ \\
\end{tabular} & Score & 2015 & 2016 & \begin{tabular}{|c|} 
Absolute \\
change
\end{tabular} & Score & 2015 & 2016 & $\begin{array}{l}\text { Absolute } \\
\text { change }\end{array}$ & Score \\
\hline Number of SMEs & 4,185 & 3,142 & $-1,043$ & 0 & 1,111 & 913 & -198 & 0 & 4,185 & 5,804 & $+1,619$ & 10 \\
\hline $\begin{array}{l}\text { Number of employ- } \\
\text { ees in SMEs (ths } \\
\text { people) }\end{array}$ & 135.61 & 124.44 & -11.17 & 0 & 38.46 & 34.94 & -3.52 & 5 & 135.61 & 164.04 & +28.43 & 10 \\
\hline $\begin{array}{l}\text { Share of the popu- } \\
\text { lation employed in } \\
\text { regional SMEs (\%) }\end{array}$ & 7.3 & 6.7 & -0.6 & 5 & 9.1 & 8.5 & -0.6 & 5 & 7.0 & 8.4 & +1.4 & 5 \\
\hline $\begin{array}{l}\text { Turnover of small } \\
\text { enterprises (bln } \\
\text { rbs) }\end{array}$ & 312.80 & 308.83 & -3.97 & 0 & 44.76 & 43.02 & -1.74 & 0 & 312.80 & 547.82 & +235.02 & 10 \\
\hline $\begin{array}{l}\text { Share of SME turn- } \\
\text { over in the GRP } \\
(\%)\end{array}$ & 25.9 & 24.5 & -1.4 & 5 & 24.9 & 22.2 & -2.7 & 5 & 5.3 & 9.3 & +4 & 10 \\
\hline $\begin{array}{l}\text { Total amount of tax } \\
\text { paid by SMEs, mln } \\
\text { rbs }\end{array}$ & $15,863.5$ & $15,612.8$ & -250.7 & 0 & $2,489.5$ & $2,612.5$ & +123 & 5 & $112,769.1$ & $124,455.7$ & $+11,686.6$ & 10 \\
\hline $\begin{array}{l}\text { Funds spent on } \\
\text { SME support (from } \\
\text { federal and regional } \\
\text { budgets) (mln rbs) }\end{array}$ & 411.1 & 302.5 & -108.6 & 0 & 301.9 & 114.8 & -187.1 & 0 & 319.8 & 172.0 & -147.8 & 0 \\
\hline $\begin{array}{l}\text { Number of } \\
\text { financial support } \\
\text { recipients }\end{array}$ & 96 & 120 & +24 & 10 & 3,968 & 1,245 & $-2,723$ & 0 & - & - & - & - \\
\hline $\begin{array}{l}\text { Number of non-fi- } \\
\text { nancial support } \\
\text { recipients }\end{array}$ & 18,230 & 18,250 & +20 & 5 & - & - & - & - & 5,191 & - & - & - \\
\hline $\begin{array}{l}\text { Jobs created by } \\
\text { recipients of SME } \\
\text { support }\end{array}$ & 120 & 363 & +243 & 10 & 2,100 & 2,800 & +700 & 10 & 1,204 & 733 & -471 & 0 \\
\hline $\begin{array}{l}\text { Capital investment } \\
\text { (bln rbs) }\end{array}$ & 8306.4 & 5604.3 & -2702.1 & 0 & 1860.6 & 1495.2 & -365.4 & 0 & 1641.5 & 1753.0 & +111.5 & 5 \\
\hline Total score & & & & 35 & & & & 30 & & & & 60 \\
\hline
\end{tabular}

Source: Based on the data of the Report on the Implementation of State Program Comprehensive Support for SME Development in Chelyabinsk Region in 2015-2017 as of 2015; Report on the Implementation of State Program Economic Development and Innovation Economy of Chelyabinsk Region in 2016-2019 as of 2016; Report on the Implementation of State Program in Tyumen Region Development of SMEs and the Knowledge-Intensive Sphere Until 2020; the Decree of 16 June 2015 No 3817 on the information of Tyumen government about the implementation of the law On SME Development in Tyumen Region; Annual Report on the Implementation and Efficiency Evaluation of State Program in Kurgan Region On SME Development and Support in Kurgan Region in 2014-2020 as of 2016; Report on the Performance Results and Key Activity Areas of the Economic Development Department of Kurgan Region in 2018-2020 as of 2017; No 1-HM Form Report on Taxies and Levies Paid to the Budget System of the Russian Federation (Federal Tax Service). 
The business information agency Rankings and News ranks Tyumen higher than Chelyabinsk and Kurgan, which ranked almost identically, in terms of entrepreneurial activity. Thus, Tyumen region scores 10 in this indicator while Chelyabinsk and Kurgan, only 5.

\section{Conclusion}

The economic security ranking of the Ural Federal District looks the following way: Chelyabinsk region, 85; Kurgan region, 75; and Tyumen region, 115. All the regions in our analysis were classified as ' $\mathrm{B}$ ' regions, which means that they have a medium (acceptable) level of economic security. The risk level is also acceptable but it should be under constant monitoring. The development of SMEs in these regions is stable and the state support in this sphere is efficient.

The ranking of the regions according to their economic security levels looks the following way:

1. Tyumen region (115).

2. Sverdlovsk region (100).

3. Chelyabinsk region (85).

4. Kurgan region (75).

On average, the Ural Federal District scores 92.5 and is characterized by a medium (acceptable) level of economic security. Tyumen re- gion, which also includes the Khanty-Mansiysk Autonomous District and the Yamal-Nenets Autonomous District, is the top performer in this respect. In this region, purchasing power is quite high and the same can be said about the factor endowments. Risks are comparatively low and are compensated for by the region's significant economic potential.

Sverdlovsk region enjoys such advantages as a well-developed internal market, large enterprises and comparatively high purchasing power of the population. These are the key factors contributing to the development of SMEs in this region. Improved indicators in SME development will signify that the region has achieved a higher level of economic security and will allow Sverdlovsk region to rise in the ranking.

As for Chelyabinsk region, there is a whole set of problems that need to be addressed in order to enable the region to make any short-term improvements in its economic security. Moreover, both Sverdlovsk and Chelyabinsk regions are heavily dependent on federal subsidies. Kurgan region is characterized by a rather low level of development of local market outlets, of the factor endowments and, therefore, has to deal with considerable risks.

\section{References}

1. Tatarkin, A. I., \& Kuklin A. A. (2012). Changing the Paradigm of Region's Economic Security Research. Ekonomika regiona, 2, 25-39.

2. Glaziev, S. Y. (2015). On Urgent Measures to Enhance Economic Security and Advanced Economic Development of Russia. Rossiysky ekonomichesky zhurnal, 5, 3-62.

3. Korableva, A. A. (2016). Interregional Comparisons in the Context of Economic Security. Vestnik of Samara State University of Economics, 10, 18-27.

4. Mingaleva, J. A., \& Gershanok, G. A. (2012). Sustainable Development in the Region: Innovation, Competitiveness and Economic Security. Ekonomika regiona, 3, 68-77.

5. Podprugin, A. V., \& Golyashina, E. A. (2015). State Support for Small Businesses as a Way to Enhance Regional Economic Security. Prioritetnye nauchnye napravlenia: ot teorii k praktike, 18, $160-164$.

6. Sarkisyan, A. D. (2017). Economic Security of Small Business as an Indicator of Stability of the Regional and National Economic System. Nauka i obrazovanie: khozyaystvo i ekonomika; predprinimatelstvo; pravo i upravlenie, 10, 96-99.

7. Ribeiro-Soriano, D. (2017). Small Business and Entrepreneurship: Their Role in Economic and Social Development. Entrepreneurship \& Regional Development, 29(1-2), 1-3. doi: $\underline{10.1080 / 08985626.2016 .1255438}$

8. Acs, Z., Åstebro, T., Audretsch, D., \& Robinson, D. T. (2016). Public Policy to Promote Entrepreneurship: a Call to Arms. Small Business Economics, 47(1), 35-51. doi: 10.1007/s11187-016$\underline{9712-2}$

9. Arshed, N., Mason, C., \& Carter, S. (2016). Exploring the Disconnect in Policy Implementation: A Case of Enterprise Policy in England. Environment and Planning C: Government and Policy, 34(8), 1582-1611. 
10. Autio, E., \& Rannikko, H. (2016). Retaining Winners: Can Policy Boost High-Growth Entrepreneurship? Research Policy, 45(1), 42-55. doi: 10.1016/j.respol.2015.06.002

11. Bondonio, D., Geenbaum, R.T. (2014). Revitalizing Regional Economies through Enterprise Support Policies: an Impact Evaluation of Multiple Instruments. European Urban and Regional Studies, 21(1), 79-103. doi: 10.1177/0969776411432986

12. Kuril, J. (2018). Protection of the State and Society: Public Administration and Public (State) Service. Journal of Security and Sustainability, 7(3), 409-416. doi: 10.9770/jssi.2018.7.3(3)

13. Korchagina, I. V. (2016). Characteristics of Regional Economic Policy to Develop Clusters of Small-Size Enterprises. Strategia ustoychivogo razvitia regionov Rossii, 35, 113-117.

14. Fotopoulos, G., \& Storey, D. J. (2018). Public Policies to Enhance Regional Entrepreneurship: Another Programme Failing to Deliver? Small Business Economics, doi: 10.1007/s11187-018-0021-9

15. Huggins, R., Prokop, D., \& Thompson, P. (2017). Entrepreneurship and the Determinants of Firm Survival within Regions: Human Capital, Growth Motivation and Locational Conditions. Entrepreneurship and Regional Development, 29(3-4), 357-389. doi: 10.1080/08985626.2016.1271830

16. Aidis, R. (2005). Institutional Barriers to Small- and Medium-Sized Enterprise Operations in Transition Countries. Small Business Economics, 25(4), 305-317. doi: 10.1007/s11187-003-6463-7

17. Bateman, M. (2000). Neo-Liberalism, SME Development and the Role of Business Support Centers in the Transition Economies of Central and Eastern Europe. Small Business Economics, 14(4), 275-298. doi: 10.1023/A:1008170805013

18. Nguyen, B., Mickiewitcz, T., \& Du, J. (2018). Local Governance and Business Performance in Vietnam: the Transaction Costs' Perspective. Regional Studies, 52(4), 542-557.

\section{Information about the authors}

Natalya Yu. Vlasova - Professor, Department of State and Municipal Management, Ural State Economic University (62/45, 8 Marta/Narodnoi voli St., 620144 Ekaterinburg, Russia); e-mail: nat-vlasova@yandex.ru.

Olesya O. Kalganova - Master Student, Department of State and Municipal Management, Ural State Economic University (62/45, 8 Marta/Narodnoi voli St., 620144 Ekaterinburg, Russia). 